\title{
International Committee on Systematic Bacteriology Subcommittee on Taxonomy of Brucella
}

\author{
Minutes of the Meeting, 4 and 5 September 1978
}

Munich, F.R.G.

Minute 1. Call to order. The Subcommittee met on 4 and 5 September 1978.

Minute 2. Record of attendance. Members present were W. J. Brinley Morgan (Chairman), M. J. Corbel (Secretary), G. M. Brown, R. Diaz, G. Gargani, Y. Isayama, L. M. Jones, N. B. McCullough, M. E. Meyer, J. M. Verger, and W. Wundt. G. G. Alton, T. Suto, and A. Weber were also present at the invitation of the Chairman.

Minute 2. Deceased member. The Chairman opened the meeting by announcing the sad news of the death of A. W. Stableforth, a founder member and former Chairman of the Subcommittee. As a mark of respect the members stood in silence for a short time.

Minute 3. New members. New members proposed since the last meeting were G. M. Brown and J. M. Verger. At the current meeting A. Weber was invited to become a member of the Subcommittee.

Minute 4. Past activities. In the 4 years since the last meeting, the members of the Subcommittee have been active by correspondence and collaborated in producing a commemorative issue of Annali Sclavo dedicated to the memory of Alice C. Evans (M. J. Corbel and G. Gargani, ed., Annali Sclavo, vol. 19, no. 1, 1977).

Minute 5. Brucella suis biotype 4. The Subcommittee considered the status of $B$. suis biotype 4 in the light of a paper by P. A. Vershilova, A. F. Pinigin, S. P. Merinov, E. A. Dranovskaya, and L. V. Gorban, "On the taxonomy of Brucella suis cultures biotype IV, isolated from the Northern reindeer." It was concluded that there was insufficient reason to reclassify this biotype at the present time. It was regretted that no Subcommittee representatives from the U.S.S.R. were present to provide further information on the properties of Brucella strains isolated from reindeer.

Minute 6. Rodent strains. The properties of Brucella strains isolated from rodents were discussed in relation to a paper by E. I. Kaitmasova, I. F. Taran, and E. A. Dranovskaya, "Characteristics of Brucella strains isolated from murine rodents in some areas of the USSR." It was concluded that further information was required on the properties of cultures from rodents before the taxonomic status of these could be decided. At present, it seemed that the strains so far examined most closely resembled $B$. suis although they did not fit neatly into the existing biotype structure.

Minute 7. Atypical B. suis. The taxonomic position of some atypical $B$. suis cultures isolated in South America was discussed. The properties of these strains, which most closely resembled $B$. suis biotype 3 except for their production of $\mathrm{H}_{2} \mathrm{~S}$, were described in a paper by M. J. Corbel, E. L. Thomas, and K. P. W. Gill, "Examination of some atypical isolates of Brucella suis: proposal for a new biotype." It was concluded that, in view of the small number of strains isolated and their few differences from other $B$. suis strains, these cultures could not be regarded as representing a new biotype at this stage.

Minute 8. B. abortus biotype 4 . The case for considering dye-sensitive isolates of $B$. abortus biotype 4 as a new biotype was considered. Isolates of this type have been described by several groups of workers (W. J. B. Morgan, J. Gen. Microbiol. 30:437-443, I. D. Farrell and L. Robertson, J. Hyg. 65:165-172, 1967; and others). They resemble $B$. abortus biotype 2 except for giving a positive agglutination reaction with $\mathrm{M}$ monospecific antiserum rather than A monospecific serum. As fewer than 20 strains have been isolated so far, it was decided that the formation of a new biotype was not justified at present.

Minute 9. Atypical B. abortus. The properties of 181 atypical cultures of $B$. abortus isolated in Senegal were described in a paper by J. M. Verger, M. Grayon, M. P. Doutre, and F. Sagna, "Characteristics of Brucella abortus strains of bovine origin isolated in Senegal." These strains were oxidase negative and gave anomalous oxidation rates with $\mathrm{L}$-asparagine, $\mathrm{L}$ arabinose, D-galactose, and D-xylose. Apart from these features, most of the isolates closely resembled $B$. abortus biotype 3 . The Subcommittee agreed that these cultures should be subjected to further examination. M. J. Corbel and M. E. Meyer undertook to examine 24 strains representative of this group and to keep the Subcommittee informed of their observations.

Minute 10. Species status. It was agreed that there would be no alteration in the taxonomic position of $B$. neotomae and $B$. ovis. It was recommended that $B$. canis should be given full species status.

Minute 11. B. abortus biotype 8 . The Subcommittee decided that $B$. abortus biotype 8 should be deleted from the list of biotypes, as no authentic isolate of this had been reported for many years and no reference strain was available. The position and nomenclature of the remaining $B$. abortus biotypes were to remain unchanged.

Minute 12. Effects of hormones. The observations recently reported by $\mathrm{M}$. E. Meyer on the evolution of Brucella and the effect of sex hormones on the characteristics of Brucella cultures were discussed.

Minute 13. Antigenic relationships. Recent advances in the study of antigenic relationships between Brucella spp. and organisms of other genera were discussed.

Minute 14. DNA homology. It was noted that only a 
single study on the application of deoxyribonucleic acid (DNA) hybridization techniques to Brucella taxonomy had been reported (B. H. Hoyer and N. B. McCullough, J. Bacteriol. 95:444-448 and 96:1783$1790,1968)$. In view of the technical advances which have been made in this field since this report, it was recommended that further studies on the DNA homology of Brucella strains should be performed.

Minute 15. Numerical taxonomy. Papers on the numerical taxonomy of the genus Brucella were discussed. It was suggested that extension of this system to include information provided by sophisticated techniques such as DNA hybridization might lead to a better understanding of relationships within the genus.

Minute 16. Fatty acid composition. Recent studies on the application of gas-liquid chromatography of fatty acid derivatives to Brucella taxonomy by $\mathrm{S}$. Tanaka and colleagues (S. Tanaka, R. Azuma, T. Suto, H. Hatakeyama, and Y. Isayama, Ann. Sclavo 19:67-82, 1977) were discussed.

Minute 17. Oxidative metabolic studies. The value of thin-layer chromatography for oxidative metabolism studies on Brucella cultures (E. Balke, A. Weber, and B. Fronk, Zentralbl. Bakteriol. Parasitenkd. Infektionskr. Hyg. Abt. 1 Orig. Reihe A 237:523-529, 1977) was discussed and confirmed.

Minute 18. Rough strains. Recent observations on the antigenic relationships between rough Brucella strains were discussed in connection with a paper by G. Gargani, "Some remarks about antigenic structure of rough Brucella strains." Currently, there is evidence that some antigenic diversity exists between rough strains derived from various Brucella spp. and the situation is more complex than the simple sharing of a common $\mathbf{R}$ antigen.

Minute 19. New phages. Since the last Subcommittee meeting, a number of new phages showing a much greater range of lytic activity have been isolated.
These include the Firenze (Fi) group, phages $\mathrm{MC} / 75$ and $\mathrm{D}$, the Berkeley phages $\left(\mathrm{Bk}_{\mathbf{0}}, \mathrm{Bk}_{1}\right.$, and $\left.\mathrm{Bk}_{2}\right)$, and phage $\mathbf{R}$.

Minute 20. ATCC cultures. It was noted that many of the Brucella cultures held by the American Type Culture Collection (ATCC) were old and atypical. It was recommended that these should be replaced as reference cultures by the recommended neotype/reference strains.

Minute 21. Publication. A detailed description of techniques for the identification and classification of Brucella cultures has been prepared for publication by M. J. Corbel and colleagues (M. J. Corbel, C. D. Bracewell, E. L. Thomas, and K. P. W. Gill, in Identification Methods for Microbiologists, 2nd ed., Academic Press, New York, 1979), and this was presented for the scrutiny and comments of the Subcommittee.

Minute 22. Correspondence. The Subcommittee recommended that a more active correspondence between members should be pursued between meetings and than an annual circular covering matters of interest should be issued.

Minute 23. Current membership. The current membership of the Subcommittee is as follows: W. J. Brinley Morgan, (Chairman), Weybridge, U.K.; M. J. Corbel, (Secretary), Weybridge, U.K.; G. M. Brown, Ames; Iowa, U.S.A.; R. Diaz, Pamplona, Spain; E. A. Dranovskaya, Moscow, U.S.S.R.; G. Gargani, Florence, Italy; Y. Isayama, Tokyo, Japan; L. M. Jones, Madison, Wis., U.S.A.; N. B. McCullough, East Lansing, Mich., U.S.A.; M. E. Meyer, Davis, Calif., U.S.A.; J. M. Verger, Nouzilly, France; A. Weber, Erlangen, F.R.G. Corresponding members: G. C. Van Drimmelen, Onderstepoort, South Africa; P. A. Vershilova, Moscow, U.S.S.R.; W. Wundt, Mannheim, F.R.G.

M. J. Corbel, Secretary

\title{
International Committee on Systematic Bacteriology Subcommittee on the Taxonomy of Mollicutes
}

\author{
Minutes of the Meeting, 27 and 30 August and S September 1978
}

Freiburg and Munich, F.R.G.

Session 1. Closed meeting.

Minute 1. Call to order. A closed meeting was called to order at 10:30 a.m. on 27 August 1978 by the Chairman, E. A. Freundt.

Minute 2. Record of attendance. Members present were: E. A. Freundt, Chairman, R. F. Whitcomb, Secretary, M. F. Barile, J. M. Bové, G. S. Cottew, H. Ern $\varnothing$, R. M. Lemcke, S. Razin, D. Taylor-Robinson, and J. G. Tully. The Chairman of the Board for the Programme on Comparative Mycoplasmology, P. Whittlestone, attended the meeting ex officio.

Minute 3. Report of the Chairman. The activities of the Subcommittee since the previous meeting in London in 1976 were summarized by the Chairman. These included preparation of a revised minimal standards document intended to replace the document set forth 